\title{
Joaquim Norberto e o indianismo
}

Roberto Acízelo de Souza Universidade do Estado do Rio de Janeiro/CNPq/FAPERJ

Resumo: O indianismo na literatura e na cultura brasileiras do século XIX, e análise de sua assimilação por Joaquim Norberto, como crítico literário, historiador epoeta.

Palavras-chave: Brasil, Nacionalismo, Século XIX.

Em 1823, o advogado Francisco Gomes Brandão (1794-1870) - que viria a ser destacada figura na vida política e intelectual do País: deputado, ministro, titular do Império, conselheiro de estado, senador, membro fundador do Instituto Histórico e Geográfico Brasileiro -, consumada a independência do Brasil, pela qual lutara, renega seus tradicionais sobrenomes portugueses, passando a assinar-se Francisco Jê Acaiaba Montezuma, inscrevendo assim no próprio nome, cheio de orgulho nativista, a identidade indígena que se atribuía. ${ }^{1} \mathrm{O}$ gesto foi

1. Mais de trinta anos depois, quando o imperador lhe outorga título de nobreza (1854), Montezuma permanece fiel à onomástica indígena, tanto que se torna visconde de Jequitinhonha. Aliás, o Império teve uma preferência especial pela toponímia indígena para nomear os seus nobres: dos 990 titulares, quase metade, 430, ostentava nomes indígenas (CANDIDO. Literatura de dois gumes, p. 175). 
comum na época, ${ }^{2}$ como afirmação nacionalista naqueles tempos de entusiasmos patrióticos com a recente independência, e comprova, entre diversos outros sinais de significado análogo, ${ }^{3}$ que a eleição do índio como símbolo heroico da nação precedeu - e parece mesmo ter preparado - sua consagração literária mediante a corrente do romantismo brasileiro conhecida como indianismo. Com efeito, embora se possam rastrear alguns prenúncios desse movimento nas décadas de 1820 e 1830, bem como na primeira metade da década de $1840{ }^{4}$ é somente a partir de

2. Na verdade, essa prática da adoção de nomes indígenas como alarde nativista tem antecedentes no século XVIII. O autor do conhecido poema "Descrição da Ilha de Itaparica" (publicado em 1769) adotou o nome de frei Manuel de Santa Maria Itaparica; o jesuíta Francisco de Faria, e certo doutor Manuel Tavares de Siqueira e Sá, adotaram respectivamente os pseudônimos de Cové Xenheenga e Anhé Pai Abaré, sob os quais assumiram a direção do ato acadêmico conhecido como "academia dos seletos", celebrado em 1752 em homenagem a Gomes Freire de Andrada (SILVA. História da literatura brasileira, p. 272).

3. Já nas solenidades políticas do Brasil joanino, o índio aparece representando o País (CANDIDO. Formação da literatura brasileira, v. 2, p. 18), e com a independência o recurso se amplia: faz-se o aborígene presente nos painéis e estátuas que ornamentavam casas nobres, nos nomes de jornais políticos do tempo - O Tamoio (1823), O Caramuru (1832), O Carijó (1832), O Indígena do Brasil (1833), O Tamoio Constitucional (1833) —, em pseudônimos da Maçonaria — D. Pedro I era Guatimozim, e José Bonifácio, Tibiriçá —, e, a partir de 1826, nos desfiles comemorativos da independência da Bahia uma ala de caboclos é que dramatizava a vitória brasileira sobre os portugueses na batalha do 2 de julho (CALMON. História social do Brasil, p. 221-223).

4. No plano do ensaio, Borges de Barros (visconde de Pedra Branca) esboça a primeira caracterização do português brasileiro, nas suas diferenças em relação ao do Portugal, inventariando palavras de origem indígena usadas somente no Brasil (1824-1825), ao que se seguem o "Ensaio sobre a história da literatura brasileira" (1836), de Gonçalves de Magalhães, e as "Considerações gerais sobre a literatura brasileira" (1844), de Joaquim Norberto. No plano da poesia, registram-se as composições: "Metamorfose original: Moema e Camarogi" e Paraguaçu (1833), de Ladislau dos Santos Titara; "Nênia" (1837), de Firmino Rodrigues Silva; "O filho do prisioneiro" (1844), de Joaquim Norberto; "Cântico do Tupi", "Imprecação do índio" e "Prisioneiro índio" (1844), de Cardoso de Meneses. Cabe ainda registrar a contribuição do grupo que Antonio Candido caracterizou como representante de um "pré-romantismo francobrasileiro", constituída por obras de autores franceses dedicadas à questão do índio brasileiro, que exerceram influência sobre os nossos primeiros românticos: Élegies brésiliennes (1823), de Édouard Corbière; "Les 
1846, com a publicação dos Primeiros cantos, de Gonçalves Dias, que o indianismo se consolida, mantendo-se vigoroso até em torno de 1865 (ano da publicação de Iracema), quando começa a declinar, processo que se estende até por volta de 1875, ano em que aparece uma das últimas realizações dentro do seu espírito, o volume de poesia Americanas, de Machado de Assis.

Esses quase 30 anos de desdobramento do indianismo coincidem em boa parte com a trajetória literária de Joaquim Norberto de Sousa Silva (18201891), figura das mais operosas e ecléticas do nosso Oitocentos, e que como tal não deixou de dar a sua contribuição ao movimento. Como se trata de autor pouco estudado, e a parte indianista de sua obra não foge à regra, nosso propósito aqui será examinar em detalhe este ângulo de sua produção.

Joaquim Norberto exercitou-se em todos os gêneros literários stricto sensu, sendo autor de extensa obra lírica, dramática e narrativa, que contudo jamais contou com grande apreço de seus contemporâneos, e menos ainda da posteridade. Destaca-se, porém, nos campos da historiografia e dos estudos literários, certamente menos pelo refinamento de seu instrumental teórico-analítico e insights críticos do que pelo pioneirismo, aplicação e rigor na pesquisa documental.

Figura entre os mais jovens da nossa primeira geração romântica, ${ }^{5}$ e professou com entusiasmo o nacionalismo político e literário característico de sua época. Basta dizer que adotou vez por outra em seus escritos o pseudônimo Fluviano (de fluvius, rio, alusivo pois à sua cidade natal, o Rio de Janeiro), e aderiu à moda dos nomes próprios de apelo indígena ou nativista, utilizando-os no batismo de seus quatro filhos homens: Artur Niteroino, Oscar Guanabarino, Armando Fluviano e João Sapucaíno. Não poderia, pois, ter ficado alheio à sedução do indianismo literário, que praticou como crítico literário, historiador e poeta.

Machacalis", novela inserida nas Scènes de la nature sous les tropiques et de leur influence sur la poésie (1824), de Ferdinand Denis; "Résumé de l'histoire littéraire du Brésil", de Ferdinand Denis; a tradução do Caramuru (1829), de Santa Rita Durão, por Eugène de Monglave; Jakaré-Ouassou, ou Les Tupinambas (1830), novela de Daniel Gavet e Philippe Boucher.

5. Nasceu em 1820, quando Gonçalves de Magalhães, por exemplo, é de 1811 
Examinemos a seguir suas produções indianistas em cada um desses gêneros.

Em 1844, numa época em que a literatura brasileira estava ainda longe de ter a sua primeira história sistemática, Norberto já se inscreve entre os pioneiros desse esforço, publicando, num periódico romântico do Rio de Janeiro, a Minerva Brasiliense, o ensaio intitulado "Considerações gerais sobre a literatura brasileira". Todo o longo primeiro parágrafo do texto, bordado com o exotismo sonoro das palavras de origem tupi (muremurés, membis, tabas, pajés, Anhangá, Juruparis, Tupaberaba, Tupaçununga, etc.), é consagrado a uma caracterização dos índios - "um povo heroico que merece de ser cantado" ${ }^{6}$, com base nos cronistas coloniais romanticamente reinterpretados. Em seguida, propõe-se uma periodização não muito clara, que estabelece três fases para a história e a literatura pátrias: a pré-cabralina, a colonial e a do presente pós-independência, caracterizado este como "pobre e mesquinho, [...], de transição", porém promissor de um "futuro [...] rico e infinito como a ideia de Deus". ${ }^{7}$ Por outro lado, o ensaísta valoriza a cultura indígena como manancial a ser explorado pela emergente literatura brasileira:

[Os índios] representavam no meio das florestas os primitivos tempos de inocência e singeleza [...]. Seus costumes, suas usanças, suas crenças forneceram o maravilhoso tão necessário à poesia [...]. ${ }^{8}$

Não temos [castelos feudais, justas, torneios, lidas e combates de ricos homens], mas possuiremos a idade desses povos primitivos [os índios] com todas as suas tradições, costumes, usanças e crenças cheias de um maravilhoso verdadeiramente poético [...]. Possuímos igualmente a nossa idade média".

6. SILVA. História da literatura brasileira, p. 331.

7. SILVA. História da literatura brasileira, p. 337.

8. SILVA. História da literatura brasileira, p. 332.

9. SILVA. História da literatura brasileira, p. 334-335. 
Anos mais tarde, num momento em que o indianismo já se afirmara plenamente, tanto no registro que deplorava a tragédia da conquista (Gonçalves Dias) quanto no que a celebrava como aurora da civilização brasileira (Alencar), Norberto voltaria ao assunto, em textos que publicou no ano de 1859. Além de tocá-lo de passagem no primeiro capítulo do longo preâmbulo teórico de sua História da literatura brasileira ${ }^{10}$ - "Introdução histórica sobre a literatura brasileira" -, dedicou-lhe, nesse mesmo preâmbulo, dois capítulos inteiros.

O primeiro, na mesma linha do estudo de 1844, se intitula "Tendências dos selvagens brasileiros para a poesia", tendo por ementa: "Tribos que mais se avantajaram na cultura da poesia. Poesias dos selvagens brasileiros". Fora transcrições de longas passagens dos cronistas coloniais, que pretendiam resumir mitos e costumes indígenas, defende uma tese - digamos assim - "simplesinha", segundo a qual, conforme o título do ensaio, os selvagens do Brasil, e em especial os Tamoios, teriam pronunciada "tendência" para a poesia:

Os Tamoios foram, entre todos os povos primitivos do Brasil, os que mais se distinguiram no cultivo da poesia, e eram eles porventura os que habitavam a mais poética de todas as situações do país. Sob o pomposo e magnífico céu do Rio de Janeiro, ante as cenas portentosas da sua natureza, à vista de sua esplêndida, pitoresca e risonha baía, só não seria poeta um povo estúpido, destituído de toda a inteligência. ${ }^{1}$

No entanto, ao mesmo tempo que exalta a capacidade poética dos indígenas, o autor é contraditório ao pronunciar-se sobre os méritos que teria a poesia dos selvagens. Assim, se ora lhes assinala a qualidade -

Esses usos, esses costumes, essas tradições, essas crenças, esses mitos deviam concorrer para o maravilhoso da sua poesia e dar-lhe o cunho

10. A obra, aliás, teria sido a primeira do gênero, não fosse a circunstância de o autor, por razões que não são bem conhecidas, ter abandonado o projeto. Chegou a publicar apenas os capítulos correspondentes grosso modo ao preâmbulo teórico, todos na Revista Popular, de 1859 a 1862. Somente no início do século XXI tais capítulos seriam recolhidos e publicados em volumes, nas edições mencionadas nas Referências, respectivamente de 2001 e 2002.

11. SILVA. História da literatura brasileira, p. 170. 
da originalidade. A língua dos Tupis, por demais poética, devia contribuir para a harmonia de seus versos e variedade das rimas. ${ }^{12}-$,

ora lhes acentua a monotonia e o primitivismo:

[...] esses povos, pelos seus usos e costumes, não podiam celebrar em seus cantos senão as suas vitórias, e quando muito não passariam de lascivas endechas; ao menos os anciãos, nas suas arengas matinais, não lhes recomendavam [...] senão duas coisas: a vigilância contra os inimigos e o amor às suas mulheres. ${ }^{13}$

Por outro lado, para um pesquisador escrupuloso e "amigo dos documentos", ${ }^{14}$ como foi Norberto, devia parecer desconcertante certo obstáculo à demonstração cabal da tese que defendia: afinal, onde estavam os textos que deveriam comprová-la? O autor percebeu claramente essa inconsistência, e tratou de racionalizá-la: simplesmente, os textos que poderiam confirmar as "tendências dos selvagens brasileiros para a poesia" não tinham sido conservados, por incúria dos colonizadores, especialmente os jesuítas:

Desgraçadamente houve o maior descuido em recolher esses cantos e traduzi-los na nossa língua; perderam-se no meio das florestas, como um brado misterioso, e os poucos fragmentos que nos restam não satisfazem a nossa avidez, não dizem se eles pertenciam a um povo decrépito, como quer Martius, ou saídos recentemente das mãos de Deus, como pretende Montaigne.

Os jesuítas [...], que substituíram esses cantos de guerra, essas epopeias da tradição e essas poesias do amor pelos cânticos religiosos, ou se descuidaram de conservá-los ou, se os conservaram, existem esquecidos sob a poeira das bibliotecas dos mosteiros, se é que já se não têm desencaminhado.

12. SILVA. História da literatura brasileira, p. 193.

13. SILVA. História da literatura brasileira, p. 176.

14. A expressão é de Péricles Eugênio da Silva Ramos (RAmos. Poesia romântica, p. 52).

15. SILVA. História da literatura brasileira, p. 169.

16. SILVA. História da literatura brasileira, p. 193. 
Desse modo, essa por assim dizer protoliteratura brasileira constituída pelos cantos indígenas, de riqueza desproporcional aos documentos que poderiam atestá-la, sofreria do mesmo mal que acometeu a produção colonial, pujante e diversificada, porém na maior parte desaparecida, perdidos que teriam sido tantos originais destinados a impressão na Europa, por saques de piratas, incêndios, naufrágios, de modo que - eis a fantástica conclusão do autor - teríamos uma literatura cujo "catálogo das obras perdidas [é] mais extenso que o das existentes".

O segundo capítulo de sua História da literatura brasileira dedicado à questão do índio se intitula "Catequese e instrução dos selvagens brasileiros pelos jesuítas". Sua ementa sintetiza bem o conteúdo: "Cultivo da língua pelos jesuítas. Composições feitas pelos padres. Introdução do teatro como meio civilizador: comédias, dramas pastoris, tragicomédias e alegorias dramáticas”. ${ }^{18}$ Descreve e exalta o trabalho missionário dos padres durante o período colonial, e insiste na ideia do extravio ou desaparecimento dos textos representativos de tamanha e tão meritória empresa:

Infelizmente esses sermões, esses compêndios, essas comédias, esses dramas pastoris, que reunidos em corpo constituiriam uma literatura apropriada a essas tribos semicivilizadas, mas ainda vivendo rodeadas da lembrança da sua existência bárbara, ou desapareceram com o sequestro dos bens da Companhia de Jesus na sua extinção, ou existem debaixo da poeira dos anos por esses arquivos que tão mal revolvidos têm sido; e apenas uma ou outra composição têm chegado aos nossos dias, para atestar os esforços desses missionários, sua dedicação e instrução. ${ }^{19}$

Ainda em 1859, na mesma Revista Popular, mas não como parte de sua História da Literatura Brasileira e sim como artigo autônomo, Norberto publicou um quinto texto em que, no âmbito da crítica literária, se dedicava a tema indianista. Trata-se de um breve comentário a fragmentos de poesia indígena revelados pelos naturalistas alemães Johann Baptiste von Spix e Carl Friedrich Philipp von Martius, como frutos de suas pesquisas em viagem pelo Brasil. Os poemas coletados

17. SILVA. História da literatura brasileira, p. 42.

18. SILVA. História da literatura brasileira, p. 207.

19. SILVA. História da literatura brasileira, p. 228. 
constituem um corpus reduzidíssimo: não mais do que dois, cada qual com duas quadras. Norberto reproduz os textos em língua indígena e a tradução em alemão, acrescentando versões em português, supostamente dele próprio, ao que parece a partir dos originais, uma vez que não consta que conhecesse o alemão. Seu comentário é mínimo, e elogioso, considerando "interessantes" e "originais" os poemas. Naturalmente - o que o autor terá talvez lamentado intimamente -, o corpus é exíguo demais para fornecer-lhe alternativa à teoria do desaparecimento das fontes que permitissem acesso pleno à poesia dos selvagens.

No campo da história, Norberto dedicou uma extensa monografia à questão dos indígenas e sua inserção na vida nacional. Trata-se da "Memória histórica e documentada das aldeias de índios da província do Rio de Janeiro", publicada no ano de 1854, na Revista do Instituto Histórico e Geográfico Brasileiro. ${ }^{20} \mathrm{Com}$ isso, inscrevia sua colaboração numa linhagem de trabalhos de temática afim que a Revista do IHGB vinha publicando desde o seu número inaugural, de 1839, entre os quais a memória "Brasil e Oceania", de Gonçalves Dias, lida pelo poeta em sessões do Instituto, de agosto de 1852 a junho de 1853, e estampada no tomo XVII do periódico, em $1867 .^{21}$

Consta a monografia de Norberto de duas seções, ditas respectivamente "Parte histórica" e "Parte documentada". A Parte histórica se compõe de 12 capítulos, precedidos de um preâmbulo basicamente protocolar. O capítulo primeiro, conforme diz o título, ocupa-se longamente das "Considerações gerais", ao passo que o último se apresenta como sumária "Conclusão"; cada um dos demais 10 capítulos, por sua vez, é dedicado à história particular de determinada aldeia indígena fluminense. Quanto à Parte documentada (melhor se diria, "documental”), como

20. Embora publicada em 1854, a "Memória" já tinha sido anteriormente apresentada no âmbito do IHGB: seu preâmbulo, indicando a ocasião da leitura pública, é datado de 16 de fevereiro de 1850, e, segundo informa o subtítulo, fora "laureada na sessão magna de 15 de dezembro de 1852 com o Prêmio Imperial".

21. Norberto se vincula ao Instituto Histórico e Geográfico Brasileiro em 1841, como sócio correspondente; em 1869, torna-se sócio honorário da instituição; por fim, em 1887 é eleito seu presidente efetivo, cargo que ocuparia até sua morte, em 1891. 
declara o título, consiste na transcrição de uma série de documentos, na maioria oficiais - escrituras, autos processuais, ofícios, portarias, certidões, requerimentos, etc. -, julgados pertinentes para a reconstituição histórica empreendida pelo autor. Impressiona pelo volume: são redondas 100 peças, totalizando 251 páginas, contra as 191 ocupadas pela Parte histórica.

No preâmbulo, explicita-se o objetivo do trabalho: com base na concepção ciceroniana de história como mestra da vida, contribuir para os debates de então sobre colonização e catequese, considerados "os dous únicos meios de promover o aumento da deficiente povoação do vasto império americano - já pela superabundância de população na Europa sucumbindo à fome, - já pelas demonstrações que patenteiam os nossos indígenas para se aldear." ${ }^{22}$ Para o alcance de tal meta, o autor expõe o procedimento que adotará, tendo em vista o diagnóstico que faz das fontes de que se serviu na pesquisa:

A incerteza que reina nas crônicas antigas, as dúvidas suscitadas pelos modernos viajantes, as ambiguidades existentes nos documentos que li, examinei ou revolvi, dão lugar a muita confusão. Para conhecer todas essas tribos errantes, que mudavam de habitação, ou por sua própria vontade, ou expelidas à força pelos seus inimigos, ou compelidas pelas devastações dos europeus, é necessário caminhar com os conquistadores, seguindo essas bandeiras, que penetravam pelos sertões para os fatais descobertos ou descimentos, marchando par a par com a civilização que os foi aldear. Neste caso a geografia e a cronologia, como olhos da história, mostrarão melhor os sítios que dominavam, quando tratar da narração peculiar do estabelecimento de cada aldeia, objeto fundamental desta memória.

Não se pode dizer, contudo, que seu esforço de reduzir a "confusão" que encontrou nos registros sobre o tema tenha sido bem sucedido. Muito pelo contrário, as generalidades de que se ocupa no primeiro capítulo não passam de uma sequência de informações apresentadas sem ordem, em que nada consegue esclarecer, por exemplo, sobre as relações étnicas e históricas entre os vários

22. SILVA. Memória histórica e documentada das aldeias de índios da província do Rio de Janeiro, p. 109.

23. SILVA. Memória histórica e documentada das aldeias de índios da província do Rio de Janeiro, p. 128-129. 
grupos indígenas a que se refere. Para se ter uma ideia das imprecisões em que incorre, veja-se, como ilustração, a passagem em que tenta caracterizar esses grupos, que se estende da página 122 à 127 do texto. Começa falando dos Tamoios, que diz descenderem dos Tupis; a seguir, menciona os Goianases, Goitacases ou Guarulhos, que por seu turno seriam aliados dos Tupinambás, os quais teriam chegado ao Rio de Janeiro antes dos Tupiniquins; prossegue referindo os Tuminós ou Tupiminós, e depois introduz os Coropós, os Coroados e os Puris, apresentados como prováveis descendentes dos Goitacases; cita em seguida certos Tapanases, inimigos dos Goitacases, e acrescenta que estes últimos se dividiam em três "cabildas": Goitacamopi, Goitacaguaçu e Goitacajacoritó; não esquece dos Sacurus, e então, quando o leitor mais paciente e tolerante já se teria perdido, arremata com menção aos Aimborés ou Aimorés, ditos também Boticudos ou Gamelas.

Num assomo de autocrítica, no entanto, reconhece que as suas "Considerações gerais" mais não fizeram senão reduplicar a confusão que criticara:

É tempo já de concluir esta tão longa quão mal esboçada introdução: pertence à história o seu desenvolvimento, e só nela se poderá expor com ordem e método o que tão confuso e sem nexo aqui aparece. É tempo pois de entrar na história das aldeias de índios da província do Rio de Janeiro $[\ldots]^{24}$

Observe-se que, nesta passagem, o autor reitera a convicção de que a "Memória", se tiver algum valor, será muito mais pelas exposições factuais dos capítulos dedicados à história de cada aldeia ${ }^{25}$ do que por sua força reflexiva e capacidade de propor conceitos propriamente críticos. Com efeito, para dizer pouco, são muito singelas as "ideias" que se podem extrair da obra. Façamos um esforço para identificá-las e descrevê-las.

Em primeiro lugar, encontramos uma espécie de comedida defesa sentimental dos aborígenes, contra seus detratores: "[...] por mais ferozes que os pintem os historiadores, não eram, nem são, destituídos da mais bela inteligência." ${ }^{26}$;

24. SILVA. Memória histórica e documentada das aldeias de índios da província do Rio de Janeiro, p. 158.

25. E - acrescentamos nós - por sua "Parte documentada".

26. SILVA. Memória histórica e documentada das aldeias de índios da província do Rio de Janeiro, p. 128. 
"Com exageradas cores pintam-nos alguns cronistas como ingratos, refalsados e pérfidos [...].". Ao contrário - argumenta -, os índios - "joviais por demais, [...] notáveis pela firmeza de seu caráter, pela franqueza de sua alma" ${ }^{28}$ - teriam "tão favoráveis disposições [que] não era por certo difícil chamá-los ao grêmio do cristianismo, tornando-os de rudes e selvagens homens civilizados e laboriosos." ${ }^{29}$ E, então, para explicar por que isso não se passou com a naturalidade de se esperar, apela para categorias por assim dizer psicológicas e morais: a ação dos colonizadores teria sido comprometida pela "cobiça" ou "avidez" e pela "imprudência", que não lhes permitiu conviver com o senso de "liberdade" essencial no indígena, e desse modo o drama da conquista se reduz a uma espécie de malentendido:

Assim a cobiça dos conquistadores [...] não fosse [...] tão fata[l] à liberdade dos índios! Da cultura das terras nasceu a necessidade de braços, e os índios, que a ela só obrigados se davam, foram escravizados [...]. ${ }^{30}$

[...] as dificuldades [...] que se alevantaram, que eriçaram de tropeços o trilho que parecia semeado de flores, não foram nem originadas pelos índios, nem por aqueles que tanto a peito tomaram a missão de sua conversão e catequese: - nasceram da imprudência dos conquistadores! ${ }^{31}$

Em segundo lugar, temos a tese sobre a razão da decadência das aldeias, e a proposta de uma política que enfim operasse a integração plena do indígena à vida nacional: inicialmente, a catequese jesuítica teria dado resultados exemplares, em geral neutralizando o empenho dos colonos na pura e simples escravização do índio: "Em suas aldeias reinavam os dias de paz, alegria e bonança

27. SILVA. Memória histórica e documentada das aldeias de índios da província do Rio de Janeiro, p. 133.

28. SILVA. Memória histórica e documentada das aldeias de índios da província do Rio de Janeiro, p. 128.

29. SILVA. Memória histórica e documentada das aldeias de índios da província do Rio de Janeiro, p. 133.

30. SILVA. Memória histórica e documentada das aldeias de índios da província do Rio de Janeiro, p. 115.

31. SILVA. Memória histórica e documentada das aldeias de índios da província do Rio de Janeiro, p. 133. 
da idade do ouro." "32 ; depois, com a expulsão dos jesuítas, os aldeamentos se transformam em "viveiros de escravos onde iam os colonos buscar os índios que precisavam para o serviço" " enfim, com o endurecimento da legislação colonial contra a escravidão do silvícola, e o correlativo recurso à escravização do negro africano, ${ }^{34}$ as aldeias ficaram abandonadas à própria sorte, iniciando-se um processo de declínio e degeneração ainda em curso no momento em que o autor escreve sua memória. A solução do problema, contudo, seria perfeitamente viável, implicando restaurar - isso fica implícito na proposição - a tal "idade do ouro" das aldeias, resultante da ação dos primeiros jesuítas:

Como o regulamento sobre as aldeias que vigora presentemente permite a reunião de duas ou mais aldeias em uma só, fácil seria o estabelecimento de uma grande povoação formada de todas as relíquias dessas que aí se extinguem a olhos vistos. Poder-se-ia então proceder à instrução desses míseros filhos das florestas, avesando-os igualmente ao doce jugo do trabalho, tornando-os úteis a si e a seu país; seria ela o ensaio e logo a escola para a perfeita civilização dos já aldeados e para a catequese de muitas tribos que, isoladas das grandes povoações, rodeadas de todas as reminiscências de sua existência errante e bárbara, jamais poderão ser

32. SILVA. Memória histórica e documentada das aldeias de índios da província do Rio de Janeiro, p. 138.

33. Silva. Memória histórica e documentada das aldeias de índios da província do Rio de Janeiro, p. 149.

34. Nesse ponto, as considerações do autor sobre a questão indígena suscitam pronunciamentos seus acerca da escravidão do negro. Suas ideias a esse respeito estão sumariamente apresentadas sobretudo num trecho que vai da página 146 à 148 . Correspondem a uma das correntes de opinião das elites brasileiras de então a propósito da chamada "questão servil", e que hoje espanta pela desinibição com que era adotada. Vejase: "Foi pois [Portugal] arrancar às terras africanas para as suas colônias na América esses milhares de negros, roubá-los a seus pátrios lares, tirálos de suas famílias, e condená-los ao perpétuo trabalho de uma escravidão eterna, transmitida por fatal herança à sua prole." Depois dessa condenação humanitária, contudo, quem espera a manutenção do tom se choca com a racionalização que se segue, que bem se pode qualificar de cínica: "Mas não serei eu que o criminarei por esse erro. Reino mesquinho, pobre em população ainda mesmo correspondendo à sua extensão, despovoado pelas suas conquistas, dizimado pelas suas guerras, que outro recurso lhe restava?" (SILVA. Memória histórica e documentada das aldeias de índios da província do Rio de Janeiro, p. 146.) 
trazidas à civilização sem grande dificuldade de nossa parte e sem se lhes avivar saudades inextinguíveis de suas antigas tabas ou malocas, sem se lhes acordar lembranças de seus hábitos, sem se lhes despertar recordações de suas crenças!

A humanidade, a civilização tem pois a esperar da esclarecida província do Rio de Janeiro a formação de uma povoação que seja para a catequese dos índios o que Petrópolis é para a colonização: um núcleo. ${ }^{35}$

Como se vê, na conclusão o autor se mostra consequente com o objetivo que enunciara, estabelecendo um vínculo entre a questão indígena e a da migração de estrangeiros para o Brasil: afinal, segundo seu ponto de vista, uma e outra constituíam dimensões essenciais da primeira de todas as urgências nacionais: a de providenciar um povo que viesse a preencher o grande vazio demográfico do "vasto império americano".

Se nada nos escapou do levantamento que fizemos em sua obra extensa, dispersa e de difícil acesso, Joaquim Norberto produziu, no campo da literatura stricto sensu, apenas dois textos de cunho indianista: um poema lírico e um drama.

O poema se intitula "O canto do prisioneiro", e integra um conjunto de composições autônomas publicadas na Minerva Brasiliense em 1843 e 1844, conjunto mediante o qual tentou o autor aclimatar à língua portuguesa a forma lírico-narrativa da balada de origem germânica. Compõe-se o texto de 18 estrofes, constituídas por versos alternados decassílabos e hexassílabos, e com rimas igualmente alternadas. Como em parte revela o título, conta a história de um guerreiro carijó que cai prisioneiro dos Tapuias, juntamente com seu "tenro filho". Um dia, por meios que a trama sumária e confusa não consegue explicar bem, o prisioneiro e o filho fogem. Nessa altura, corte brusco: passa a narrar-se a cena do cerco de Goiana pelos holandeses, e ficamos sabendo que a resistência dos

35. SILVA. Memória histórica e documentada das aldeias de índios da província do Rio de Janeiro, p. 263.

36. SILVA. Memória histórica e documentada das aldeias de índios da província do Rio de Janeiro, p. 109. 
pernambucanos é comandada por um índio valoroso, exatamente o filho do prisioneiro a cuja fuga tínhamos assistido em estrofe anterior. Naturalmente, os nacionais vencem aos flamengos, e a última estrofe proclama a identidade do herói, que é nada mais nada menos que Felipe Camarão, o representante índio do célebre triunvirato que comandara e vencera no século XVII a guerra contra os hereges holandeses:

\section{Curvai-vos ante o horror vitorioso, Ó batava nação!}

Saudai do prisioneiro o filho honroso, O invicto Camarão!

O poema é de 1844. Seria desleal - e forçado - considerá-lo uma antecipação, ainda que sumamente incolor, da obra-prima que é "I-Juca-Pirama" (1851), pela coincidência de ambas as composições envolverem a figura de um índio, seu filho, guerras tribais, prisão. Limitemos pois nossa atenção à data de sua publicação: esteticamente desastroso, o poema tem, no entanto - aliás como diversas outras produções de Norberto -, o acanhado mérito do pioneirismo: nos quadros da poesia indianista romântica, é precedido apenas por contribuições de Santos Titara e Firmino Rodrigues, respectivamente de 1833 e 1837, e aparece no mesmo ano em que Cardoso de Meneses lança seus poemas vinculados ao indianismo; Gonçalves Dias, por seu turno, só entraria em cena, com os seus Primeiros cantos, em 1846, isto é, dois anos depois.

Quanto ao drama - Lindoia ou Os jesuítas no Uruguai-, trata-se de peça que permaneceu inédita e nunca chegou à cena. Seu manuscrito autógrafo, datado de 30 de outubro de 1875, jaz no acervo do Instituto Histórico e Geográfico Brasileiro. Configura, portanto, um intempestivo retorno do autor à temática indianista, já que sua última incursão neste campo - depois do ensaio e do poema de 1844, e da memória histórica de 1854 -, se dera em 1859, com seus estudos sobre a poesia dos indígenas e sua alegada importância para a literatura brasileira. Não surpreende, desse modo, o generalizado anacronismo de que a obra se ressente, desde o título, com a indefectível conjunção "ou", segundo o figurino de novelas

37. SILVA. O filho do prisioneiro, p. 371.

38. Ver a propósito nota 4 . 
setecentistas e dos velhos folhetins e tragédias da primeira metade do século XIX, até o longo subtítulo que lhe revela a fisionomia geral: "Drama histórico, de assunto nacional, em 5 atos e 13 quadros, ornado de coros, recitativos, marchas guerreiras, combates, etc., etc., baseado no enredo do imortal poema de Basílio da Gama." Não é de espantar-se, por conseguinte, sua destinação, por assim dizer, a virtual inexistência: era afinal o ano de 1875, quando o longo ciclo do indianismo romântico, já então em franco declínio havia muito tempo, conheceu o que podemos considerar seu último alento e fim simbólico: a publicação das Americanas, reunião de poemas em que um Machado de Assis ainda romântico empreendia um derradeiro esforço de revitalização da corrente, não obstante a nova geração depreciá-la como antiquada poesia de borés e tacapes.

\section{Joaquim Norberto and the Indianism}

Abstract: The Indianism in the Brazilian literature and culture in the nineteenth century, and analysis of its assimilation by Joaquim Norberto, as a literary critic, a historian and a poet.

Keywords: Brazil, Nationalism, Nineteenth century.

$$
\text { Referências }
$$

ALENCAR, Heron de. José de Alencar e a ficção romântica. In: COUTINHO, Afrânio. (Dir.). A literatura no Brasil. 2. ed. Rio de Janeiro: Sul Americana, 1969. v. 2, p. 217-300.

ALENCAR, Heron de. Indianismo. In: COELHO, Jacinto do Prado. (Dir.). Dicionário de literatura brasileira, portuguesa, galega, estilística literária. 3. ed. Porto: Figueirinhas, 1973. v. 1, p. 462-464.

ALMEIDA, Carlos Eduardo de. Entre o próprio e o alheio: a construção literária da nação brasileira. São Paulo: Ômega, 2007.

BASTOS, Alcmeno. O índio antes do romantismo. Rio de Janeiro: 7Letras/ FAPERJ, 2011.

BARRETO, Dalmo. Centenário da morte de Joaquim Norberto de Sousa Silva. Revista do Instituto Histórico e Geográfico Brasileiro, Rio de Janeiro, 15 (373): 937-941, out./ dez. 1991.

CALMON, Pedro. História social do Brasil. 3. ed. São Paulo: Martins Fontes, 2002. v. 2. (Espírito da sociedade imperial). 
CANDIDO, Antonio. Formação da literatura brasileira; momentos decisivos. 4. ed. São Paulo: Martins, 1971. 2 v.

CANDIDO, Antonio. Literatura de dois gumes. In: A educação pela noite; e outros ensaios. 3. ed. São Paulo: Ática, 2000. p. 163-180.

JOBIM, José Luís. Indianismo, nacionalismo e raça na cultura do romantismo. In: As formas da teoria; sentidos, conceitos, políticas e campos de força nos estudos literários. Rio de Janeiro: Caetés, 2002. p. 87-116.

MIRANDA, José Américo. Origens do conceito de literatura brasileira: o papel de Joaquim Norberto de Sousa Silva e seu Bosquejo da bistória da poesia brasileira. C. M. H. L. B. Caravelle, Toulouse, 70: 135-150, 1998.

MOREIRA, Maria Eunice. Na rede do tempo; história da literatura e fontes primárias: a contribuição de Joaquim Norberto. In: ZILBERMAN, Regina et al. As pedras e o arco; fontes primárias, teoria e história da literatura. Belo Horizonte: Ed. UFMG, 2004. p. 119-198.

MOREIRA, Maria Eunice. Um rato de arquivo: Joaquim Norberto de Sousa Silva e a história da literatura brasileira. Cadernos do Centro de Pesquisas Literárias da PUCRS, Porto Alegre, 1 (2): 21-27, jun. 1995.

MOREIRA, Maria Eunice. (Org.). Falas diversas; quatro estudos sobre Joaquim Norberto. Porto Alegre: Centro de Pesquisas Literárias da PUCRS, 2001.

PEIXOTO, Almir Câmara de Matos. Direção em crítica literária; Joaquim Norberto de Sousa Silva e seus críticos. Rio de Janeiro: Ministério de Educação e Saúde, 1951.

PINTO, Edith Pimentel, seleção e apresentação. Introdução. In: O português do Brasil; textos críticos e teóricos - 1 - 1820/ 1920: fontes para a teoria e a história. Rio de Janeiro: Livros Técnicos e Científicos; São Paulo: Edusp, 1978. p. XV-LVIII.

PINTO, Edith Pimentel, seleção e apresentação. Visconde de Pedra Branca. In: $O$ português do Brasil; textos críticos e teóricos - 1 - 1820/ 1920: fontes para a teoria e a história. Rio de Janeiro: Livros Técnicos e Científicos; São Paulo: Edusp, 1978. p. 5-7.

RAMOS, Péricles Eugênio da Silva, introdução, seleção e notas. Joaquim Norberto. In: Poesia romântica; antologia. São Paulo: Melhoramentos, 1965. p. 52-55.

RICARDO, Cassiano. Gonçalves Dias e o indianismo. In: COUTINHO, Afrânio. (Dir.). A literatura no Brasil. 2. ed. Rio de Janeiro: Sul Americana, 1969. v. 2, p. 65-129.

ROMERO, Sílvio. Poesia: segunda fase do romantismo. In: História da literatura brasileira. [6. ed.] Rio de Janeiro: Imago; Aracaju: Universidade Federal de Sergipe, 2001. v. 2, p. 739-769.

SILVA, Joaquim Norberto de Sousa. O filho do prisioneiro; balata. Minerva Brasiliense; jornal de ciências, letras e artes publicado por uma associação de literatos. Rio de Janeiro, 12 (1): 370-371, 15 abr. 1844.

SILVA, Joaquim Norberto de Sousa. Memória histórica e documentada das aldeias de índios da província do Rio de Janeiro. Revista do Instituto Histórico e Geográfico do Brasil. Rio de Janeiro, 17 (14-15): 109-552, 2의 3o semestres 1854.

SILVA, Joaquim Norberto de Sousa. Lindoia ou Os jesuítas no Uruguai. 1875. Manuscrito inédito, pertencente ao acervo do Instituto Histórico e Geográfico Brasileiro.

SILVA, Joaquim Norberto de Sousa. Bosquejo da história da poesia brasileira. Edição, apresentação e notas de José Américo Miranda. Belo Horizonte: Ed. UFMG, 1997. 
SILVA, Joaquim Norberto de Sousa. Capítulos de história da literatura brasileira; e outros estudos. Edição e notas de José Américo Miranda \& Maria Cecília Boechat. Belo Horizonte: Faculdade de Letras da UFMG, 2001.

SILVA, Joaquim Norberto de Sousa. História da literatura brasileira; e outros ensaios. Organização, apresentação e notas de Roberto Acízelo de Souza. Rio de Janeiro: Zé Mário Ed./ Fundação Biblioteca Nacional, Departamento Nacional do Livro, 2002.

SILVA, Joaquim Norberto de Sousa. Romances e novelas. [2. ed.] Organização, apresentação e notas de Sílvia Maria Azevedo. São Paulo: Landy, 2002.

SILVA, Joaquim Norberto de Sousa. Crítica reunida; 1850-1892. Organização, introdução e notas de José Américo Miranda, Maria Eunice Moreira \& Roberto Acízelo de Souza. Porto Alegre: Nova Prova, 2005.

SODRÉ, Nélson Werneck. As razões do indianismo. In: História da literatura brasileira; seus fundamentos econômicos. 5. ed. Rio de Janeiro: Civilização Brasileira, 1969. p. $255-271$.

SODRÉ, Nélson Werneck. O indianismo e a sociedade brasileira. In: História da literatura brasileira; seus fundamentos econômicos. 5. ed. Rio de Janeiro: Civilização Brasileira, 1969. p. 272-294.

SOUZA, Roberto Acízelo de. Joaquim Norberto e sua contribuição à edição de textos e à crítica literária. Revista de Letras, São Paulo, 48:9-26, jan./ jun. 2008.

TREECE, David. Exilados, aliados, rebeldes; o movimento indianista, a política indigenista e o estado-nação imperial. Trad. Fábio Fonseca de Melo. São Paulo: Nankin/ Edusp, 2008. 